\title{
ОБЗОР ФАУНЫ МУХ ТАХИН ВИНОГРАДНЫХ АГРОЦЕНОЗОВ ДАГЕСТАНА
}

\author{
Мисриева Б.У., \\ Дагестанское представительство АО "Щелково Агрохим", \\ e-mail: misrieva.b@betaren.ru
}

https://doi.org/10.53040/9789975347204.14

\begin{abstract}
In the context of the intensive use of chemical plant protection products, the issue of ecologization is acute. The concept of environmental protection of grapes, as the most pesticidal crop, is based on the principles of managing the phytosanitary state of agrocenoses as a whole. At the same time, entomophages play a key role in the formation of a balanced self-regulating ecosystem. The development and application of the so-called biorational technologies with the predominant use of safe ecologically "soft" chemical plant protection products in the grape protection system is a prerequisite for activating a useful entomofauna. The targeted effect on the entomophage populations is based on phytosanitary monitoring, on their integration with pesticides. The article presents the results of many years of faunal studies of grape agrobiocenoses, reveals the most effective mechanisms for the regulation of dangerous bunching leaves and cotton scoops. Based on the original drawings, a morphological description of the most common species of tachy flies is given - Elodia tragica Mg., Pseudoperichaeta insidiosa, Tawnsendiellomyia nidicola.
\end{abstract}

Key words: Tahini flies, grape agrocenoses of Dagestan, entomophages, ecologization of plant protection.

\section{Введение}

Энтомофауна хищников и паразитов гроздевой листовертки и хлопковой совки в виноградных биоценозах подробно изучена и освещена в ряде работ. (Дергачев Д.В., 2000, Ширинян Ж.А., Исмаилов В.Я.; Сергиенко Г.А., 2004, Мисриева Б.У., Рамазанова 3.М., 2014, Ташпулатов М.М., Солиев Ш.Т., 2016, Мисриева Б.У., Шамсудинова М.М., 2017 и др. С целью изучения потенциала естественных регуляторов численности популяции гроздевой листовертки и хлопковой совки, на протяжении длительного времени (2008-2019гг), проводились масштабные обследования агроценозов южного Дагестана. Полученный обширный материал по фаунистическому составу энтомофагов и паразитоидов позволил выделить массовые и фоновые виды.

Тахины - эффективные паразиты многих видов гусениц чешуекрылых, личинок пилильщиков, личинок и взрослых жуков, клопов, перепончатокрылых. В регуляции численности и подавлении очагов массовых размножений вредных видов насекомых значение этих мух чрезвычайно велико.

Обширный библиографический поиск показал, что изучение фауны тахин, их трофизм и распространение в агроландшафтах в регионе не проводилось более 30 лет. Экспериментально установлено, что среди вредителей плодовых культур и винограда больше всего поражается мухами-тахинами гроздевая листовертка (13,5-32\%). С целью изучения потенциальной пригодности мух тахин северокавказских популяций в качестве регуляторов плотности популяции гроздевой листовертки и хлопковой совки на виноградниках, в течение ряда лет были проведены исследования по изучению их видового состава, хозяино-паразитных связей и распространению. Таким образом, изучение комплекса паразитических тахин, ассоциирующихся с гроздевой листоверткой и хлопковой совкой представляет как научный, так и практический интерес, с точки зрения выявления специализированных видов в природных условиях. 


\section{Материал и методы}

Объектами исследований были наиболее распространенные и вредоносные фитофаги винограда - гроздевой листовертки и хлопковой совки. Морфологические исследования насекомых сводились к микроскопии и сравнительному изучению систематических признаков, с использованием микроскопов МБС-1, МБС-9.

\section{Результаты и обсуждение}

На основе систематических наблюдений было установлено, что в виноградных агроценозах Дагестана фоновыми являлись три вида тахин: (Elodia tragica Mg., Pseudoperichaeta insidiosa u Tawnsendiellomyia nidicola.), морфология которых была изучена детально. Исследования, проведенные с декабря 2017 года по июль 2019 года, показали, что гибель личинок мух-тахин в зависимости от погоды составляла 0,9$14,5 \%$, гибель куколок - 10,6-48,6\%, продолжительность развития куколок - 10-16 дней, соотношение численности полов - от 1: 0,466 до 1:1,246 (самцы:самки), продолжительность жизни самок - 5,6-15,7 дней, плодовитость - 162,7-968,3 яйца.

Знание общих для всех видов морфологических признаков недостаточно для систематизации отдельных видов. В этой связи, нами, на основании зарисовок и соответствующих измерений было дополнено морфологическое описание наиболее распространенных видов - Elodia tragica Mg., Pseudoperichaeta insidiosa u Tawnsendiellomyia nidicola.

Ниже приведено уточненное морфологическое описание вышеуказанных мухтахин.

Все мухи обычно средней величины, скромно окрашенные с телом, усаженным крепкими щетинками. Голова полушаровидная, большую часть ее занимают расположенные по бокам крупные фасеточные глаза, которые у самцов обычно соприкасаются. Усики трехчлениковые, со спинной аристой. Передняя часть головы состоит из лба (над усиками) и лица (под усиками). Усики и лицо огибает дуговидный шов, валикообразные отделы которого называются лицевыми килями. Различают лобную полосу - среднюю часть лба, идущую от основания усиков к темени, и ее заднюю часть с глазками (теменной треугольник). Скулы - пространство между ветвями дуговидного шва и внутренними краями глаз и щеки - нижний отдел головы, расположенный ниже скул, а также «затылочное расширение» - усаженную волосами область щек, являющуюся как бы продолжением затылка, и теменные пластинки полоски кожи между лобной полосой и внутренними краями глаз.

В зависимости от положения на голове различают следующие группы щетинок: внутренние и внешние теменные, затемненные, орбитальные, лобные, глазковые, заглазковые реснички, заглазковые - позади затемненных, скуловые, вибриссальные вдоль лицевых килей.

Орбитальные щетинки находятся на теменных пластинках лба и, как правило, ограничены верхней его половиной; иногда они расположены в два продольных ряда и в этом случае различают внутренние и наружные орбитальные щетинки.

Грудь несет ноги и одну пару крыльев. Вторая пара их редуцирована и превращена в колбовидные образования - жужжальца.

При определении тахин большое значение имеет характер жилкования крыла (см. рис.), особенно форма жилки. Её отогнутая часть образует вершинную поперечную жилку, которая вливается в край крыла. Нередко главная жилка, в месте изгиба несет небольшой отросток. Имеют также значение положение средней и задней поперечных 
жилок и соотношение их длины. Брюшко тахины состоит из сокращенного количества сегментов. Сверху видно обычно четыре сегмента.

Многолетними фаунистическими исследованиями было обнаруженно и идентифицированно три конкретных вида:

Elodia tragica Mg. Наиболее распространенный вид. В экологической зоне Дербентского района Elodia tragica Mg. паразитирует гусениц хлопковой совки в июнесентябре и не влияет на развитие первой генерации вредителя.

Нами оценивалось влияние возраста и массы насекомого-хозяина на продуктивность и качество (размеры) потомства Elodia tragica Mg.

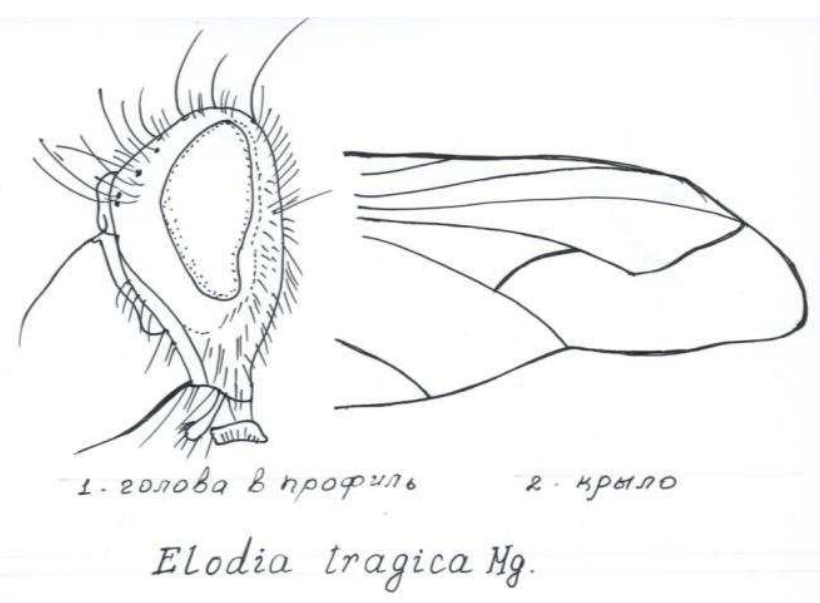

Самки откладывают яйца на гусениц гроздевой листовертки и хлопковой совки старших возрастов. Имаго паразитоида появляется в период массового лета бабочек листовертки. На основе наблюдений было установлено, что гусеницы хлопковой совки 1-2 возрастов погибают через 2,3-9,7 суток после паразитирования. Паразит продуцирует пупарии на хозяине более старших возрастов. Потребление корма и его утилизация в гусеницах хлопковой совки, паразитированных Elodia tragica Mg. в 4 возрасте, были такими же, как и у непаразитированных гусениц вплоть до 1-2 суток до вылета паразита.

С целью оценить возможности наработки энтомофага в контролируемых лабораторных условиях в качестве биоагента, был поставлен лабораторный эксперимент. В лабораторном опыте взрослых особей мухи-тахины кормили сахарозой и водой. В части вариантов 6-, 8-, 10- и 12-дн. мух переводили на питание живыми гусеницами хлопковой совки совки, гемолимфой этой совки, контрольные мухи продолжали питаться сахарозой и водой. Плодовитость мух, питавшихся с 12-дневного возраста на гусеницах или гемолимфе хозяина, была больше плодовитости контрольных мух в 4,1-7,5 раза. Разницы в плодовитости самок, питавшихся с 10дневного возраста живыми гусеницами, гемолимфой хозяина или сахарозой и водой, не наблюдали. Таким образом, было установлено время эмбрионального созревания имаго мухи Elodia tragica Mg.

Pseudoperichaeta insidiosa. С целью изучения особенностей биологии мухитахины Pseudoperichaeta insidiosa, и характера его физиологических взаимоотношений с хозяином, паразитоид выращивался на гусеницах хлопковой совки в контролируемых лабораторных условиях в специальных изоляторах. Наблюдениями было установлено, что масса паразитированных тахиной гусениц хлопковой совки достигала $76 \%$ от массы 
здоровых. Продолжительность развития последнего возраста гусениц увеличивалась до 9,6 дней при паразитировании тахиной по сравнению с 7,0 днями непаразитированных гусениц. Влияние хозяина на развитие паразита изучали на гусеницах 2-5 возрастов. При заражении гусениц 2 возраста паразит развивался почти в 2 раза дольше, чем при заражении гусениц 5 возраста. Максимальное число пупариев паразита (50\%) развивалось при заражении гусениц 3 возраста. Соответствующими замерами было установлено, что средний вес куколки Pseudoperichaeta insidiosa составляет 28,8 мг.

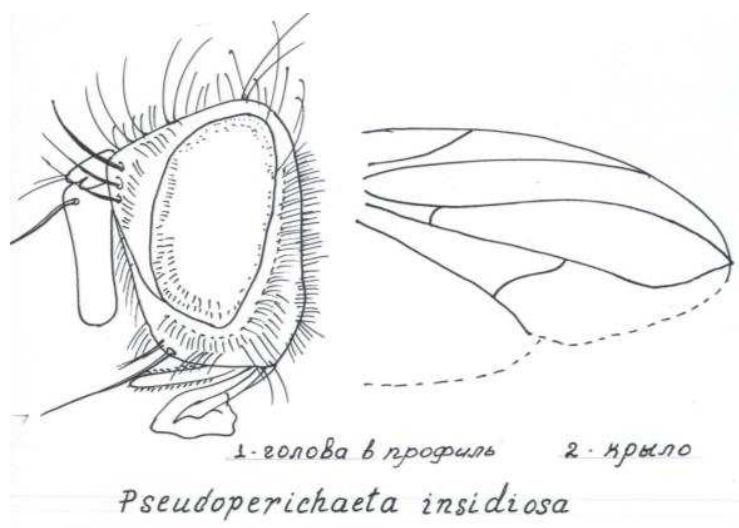

Townsendiellomyia nidicola. Townsend, 1908. В условиях южного Дагестана лет паразитоида начинается с первой декады июня. Данные по хозяино-паразитным связям и распространению вид относится к широкому полифагу. В контродлируемых лабораторных условиях плотность заселения тахинами гусениц хозяина - хлопковой совки составляет 20 личинок на гусеницу. На виноградниках зараженность гусениц совок в зависимости от применяемых инсектицидов значительно колеблется. Так, на необработанных участках пораженность гусениц составляла $65-73 \%$, а на обработанных инсектицидами - 1-12\%. Степень паразитизма хлопковой совки по 3-м поколениям в годы исследований (2017-2019 гг) была достаточно высока: в среднем 67, 55 и 43\% в июне, июле и августе соответственно. Паразитирование гусениц гроздевой листовертки наблюдалось значительно реже.

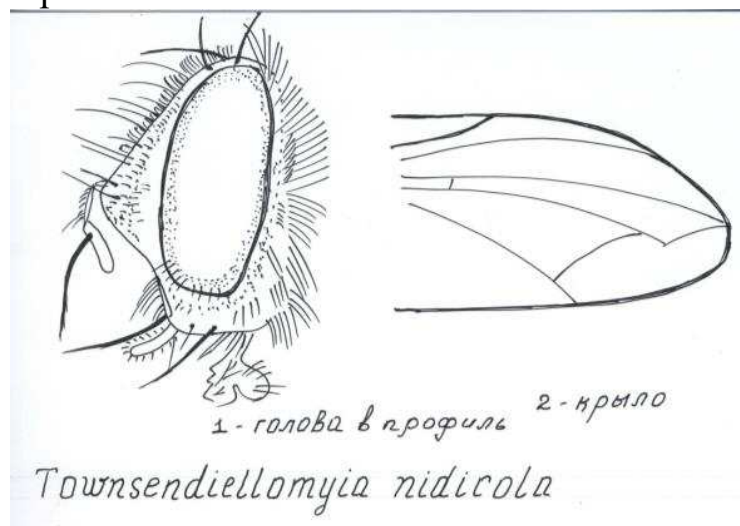

Собранные коконы и куколки совок и листоверток сортировали на пустые и полные, здоровые, больные и паразитированные. Если определение не представляло сложностей указывали причину поражения. Здоровых куколок сортировали на самцов и самок, последних взвешивали. Отмечено, что недавно зараженные куколки хозяина сохраняют ту же подвижность, что и здоровые, а 
подвижность здоровых куколок уменьшается перед вылетом бабочек. В связи с этим для определения процента паразитированности куколок необходимо или их вскрытие или сохранение куколок в какой-либо емкости до вылета из них имаго вредителя или выхода паразита.

Наблюдениями в контролируемых лабораторных условиях установлено, что куколки, содержащие внутри личинок или куколок наездников, имеют более вытянутую форму из-за растянутости брюшка куколки в межсегментальных перегородках. При анализе по экзувиям (пустым куколочным оболочкам) мы ориентировались на следующие признаки: При выходе мух-тахин на экзувии образуются неправильной формы отверстия или разрывы в сочленениях брюшка.

В 2017 году, на куколках хлопковой и других видов совок нами были отмечены энтомофторозы, по морфологии сходным с Cordyceps miiitaris. Гриб в основном паразитирует на гусеницах чешуекрылых. Идентификация требует подтверждения. Развитие энтомофторозов было отмечено единично. Но, при благоприятных условиях, гриб может получить эпизоотическое распространение.

\section{Выводы}

Впервые дан обзор фауны мух тахин виноградных агроценозов Дагестана. Показана их регулирующая роль как эффективных паразитов наиболее опасных чешуекрылых вредителей - гроздевой листовертки и хлопковой совки. Многолетними учётами и наблюдениями изучена биология, фенология и многолетняя динамика численности наиболее распространенных видов: Elodia tragica Mg., Pseudoperichaeta insidiosa и Tawnsendiellomyia nidicola.

На основе оригинальных рисунков приведены отличительные морфологические признаки, которые могут быть использованы для идентификации этих видов при проведении мониторинга.

\section{Библиография}

1. Дергачев Д.В. Биоэкологические особенности и энтомофаги гроздевой листовертки Lobesia botrana Den. et Schiff. (Lepidoptera, Tortricidae) на виноградниках Азово-Черноморского побережья России : Автореф. дис...канд. биол. наук //Краснодар, 2000. - 24 c;

2. Ташпулатов М.М., Солиев Ш.Т.Видовой состав паразитов - энтомофагов хлопковой и озимой совок на посевах томата./Фундамент. и приклад. исслед. в биоорган. сел. хоз-ве России, СНГ и ЕС // Всерос. науч.-исслед. ин-т фитопатологии. Большие Вяземы, 2016;

3. Ширинян Ж.А.,Исмаилов В.Я.,Сергиенко Г.А.Видовой состав, динамика численности и полезная роль паразитов-энтомофагов хлопковой совки (Heliothis armigera Hbn.) в условиях юга России./Материалы докладов научно-практической конференции, посвященной 100-летию со дня рождения Е.М. Степанова (1902-2002), 89 октября 2002 г., г. Краснодар. - С. 117-122;

4. Мисриева Б.У.,Рамазанова 3.М. Видовой состав и эффективность природных популяций трихограммы естественных биотопов Южного Дагестана./Проблемы развития АПК региона.- 2014.-N 4. - С. 56-58;

5. Мисриева Б.У., Шамсудинова М.М. Изучение роли перспективных видов энтомофагов в агроценозах Дагестана./Овощи России.-2017.-N 1. - С. 87-91;

6. Павлюшин В.А. Проблемы экологизации средств защиты растений (12 янв. 2016 г., Москва)./Защита и карантин растений.- 2016.- N 3. - С. 52; 
7. Власенко Н.Г., Бокина И.Г. Экологизация защиты растений в условиях интенсификации. Ж.Главный агроном.- 2018.- N 9. - С. 7-10;

8. Мартынова Г.П. Пути экологизации защиты растений в практике сельскохозяйственного производства./Инновац. развитие растениеводства в Респ. Марий Эл // Марийс. ин-т переподгот. кадров агробизнеса. - Йошкар-Ола, 2011. - С. 91 100 